DOI: $10.21122 / 1029-7448-2017-60-4-367-379$

UDC 621.311.25

\title{
The Improvement of Low-Waste Technologies of Working Body of Water Preparation at Thermal and Nuclear Power Plants
}

\author{
K. D. Rymasheuskaya ${ }^{1)}$ \\ ${ }^{1)}$ RUE “Belnipienergoprom” (Minsk, Republic of Belarus)
}

\begin{abstract}
In the present work the main directions of water desalination technologies improving have been analyzed. Possible techniques of high-quality treatment of water that enable the reduction of amounts of environmentally hazardous substances to be discharged into the hydrosphere are indicated. The purpose of the work was to improve the ecological efficiency and the effectiveness of water treatment equipment at heat power plants when designing new and the modernizing existing water treatment schemes. In order to achieve this goal the following problems have been solved: the one of analyzing the main directions of the improvement of technologies of working body of water preparation at thermal and nuclear power plants; of analyzing the main directions of reduction of total volume of highly mineralized power plant wastewaters; of developing the technological scheme of recycling of concentrate of membrane installations and regenerants of ionite filters in acid and alkali; of developing the technological scheme of transformation of the sludge in pre-processing waste into valuable commodity products. The results of research can be applied for the design of new and the modernization of existing water treatment installations of thermal and nuclear power plants. It will enable to reduce considerably the use of natural water and the amount of chemicals added as well as the volume of wastewater and the concentration of dissolved solids in it. As a consequence, the negative impact of thermal and nuclear power plants on the hydrosphere will be reduced.
\end{abstract}

Keywords: water treatment plant, low-waste technologies, water desalination, closed cycle of water use, membrane technologies of water desalination, ion exchange

For citation: Rymasheuskaya K. D. (2017) The Improvement of Low-Waste Technologies of Working Body of Water Preparation at Thermal and Nuclear Power Plants. Energetika. Proc. CIS Higher Educ. Inst. and Power Eng. Assoc. 60 (4), 367-379. DOI: 10.21122/1029-7448-201760-4-367-379

\section{Совершенствование малоотходных технологий подготовки водного рабочего тела на тепловых и атомных электрических станциях}

\author{
Е. Д. Римашевская ${ }^{1)}$ \\ ${ }^{1)}$ РУП «Белнипиэнергопром» (Минск, Республика Беларусь) \\ (C) Белорусский национальный технический университет, 2017 \\ Belarusian National Technical University, 2017
}

Реферат. Проанализированы основные направления совершенствования технологий обессоливания воды, представлены возможные пути снижения нагрузки водоподготовительных

\author{
Адрес для переписки \\ Римашевская Екатерина Дмитриевна \\ РУП «Белнипиэнергопром» \\ ул. Романовская Слобода, 5а, \\ 220048, г. Минск, Республика Беларусь \\ Тел.: +375 29 105-75-00 \\ katiarim1993@gmail.com
}

\author{
Address for correspondence \\ Rymasheuskaya Ekaterina D. \\ RUE “Belnipienergoprom” \\ 5a Romanovskaya Sloboda str., \\ 220048, Minsk, Republic of Belarus \\ Tel.: +375 29 105-75-00 \\ katiarim1993@gmail.com
}


систем на гидросферу. Предмет исследований - ресурсосбережение и повышение экологической безопасности вновь вводимого и реконструируемого водоподготовительного оборудования на тепловых электрических станциях путем проведения сравнительного анализа технологий обессоливания воды и выявления наиболее экономически и экологически выгодной схемы подготовки добавочной воды. Для достижения поставленной цели решались следующие задачи: анализ основных направлений совершенствования технологий обессоливания воды для тепловых и атомных электрических станций; исследование основных путей снижения общего количества сточных вод тепловых электрических станций; разработка технологических схем переработки концентрата мембранных установок и отработанных регенерационных растворов ионитных фильтров в кислоту и щелочь и шлама предочистки - в ценные товарные продукты. Результаты работы могут быть применены в процессе проектирования новых и модернизации существующих водоподготовительных установок тепловых и атомных электрических станций, что позволит значительно сократить использование природной воды и реагентов для регенерации, а значит, минимизировать объем сточных вод и их солесодержание и снизить за счет этого нагрузку тепловых и атомных электростанций на гидросферу.

Ключевые слова: водоподготовительная установка, малоотходные технологии, обессоливание воды, замкнутый цикл водопользования, мембранные технологии в водоподготовке, ионный обмен

Для цитирования: Римашевская, Е. Д. Совершенствование малоотходных технологий подготовки водного рабочего тела на тепловых и атомных электрических станциях / Е. Д. Римашевская // Энергетика. Изв. высш. учеб. заведений и энерг. объединений СНГ. 2017. Т. 60. № 4. C. 367-379. DOI: 10.21122/1029-7448-2017-60-4-367-379

The current state of technology of working body of water preparation on thermal power plants in the Republic of Belarus is determined by the state and prospects of development of main power equipment. Today, more than $90 \%$ of country's power is generated in thermal power plants that were commissioned lots of years ago. Traditionally used in the Belarusian energy system methods and technologies of physical and chemical treatment of natural water for steam generators feed allow to provide the high quality of desalinated water, guarantee the long-term reliable work of main power equipment, are easy to automate and to operate. Despite all the advantages of these water desalination technologies a serious problem of such water treatment plants is the use a significant amounts of chemicals and the formation of highly mineralized acidic and alkaline wastewaters as a result $[1,2]$. Under the circumstances when prices for ion-exchange resins, acid and alkali as well as expenses for water use and wastewater disposal costs are permanently increasing water treatment technologies must be improved and developed. So the aim to increase the economic efficiency of water purification systems and to reduce their negative impact on the environment is of special significance nowadays [3].

Currently, desalination for thermal power plants steam generators feed water preparation is mainly based on traditional technological schemes. These schemes include preliminary water treatment stage in sludge blanket clarifiers and filtration in clarification filters and a subsequent step of the two-stage chemical softening (by the bed of strong acid cation exchange resin in the sodium form) or desalination (which include a strong acid cation unit and a strong base anion unit). Clarification filters are loaded with granular material (hydroanthracite or crushed anthracite) to the height not more than $1.0 \mathrm{~m}[4,5]$. 
As a result of the operation of the currently used makeup water treatment plants, the highly mineralized acidic and alkaline wastewaters are formed. That is why the tasks of modern water treatment plant are [6]:

- to provide stable quality of desalinated water;

- to provide long-term reliability and operating stability of the main power equipment;

- to reduce operating costs;

- to minimize the amount of wastewater discharges.

Application of modern water desalination technologies (for pretreated water) such as counter-current ion exchange, membrane and thermal desalination technologies as well as implementation of brine concentrators followed by a brine crystallizer or an evaporation pond (designed for eliminating any liquid waste leaving the power plant while the produced solids are recovered as valuable salt byproducts) would allow to solve the problem of reduction of total volume of highly mineralized power plant wastewaters[7-9].

In the world practice of water treatment the following tendencies could be marked out [10]:

- economy of fresh water;

- reduction of chemicals used as a result of practical implementation of reagent-free methods of water desalination;

- reduction of the environmental impact of water purification systems as a result of wastewater discharges minimization;

- practical implementation of closed cycles of water use as well as technological schemes of wastewater recycling and reuse.

So recovery and recycling of wastewater is becoming a growing trend [11]. Wastewater reuse not only minimizes the volume and environmental risk of discharged wastewater, but also alleviates the pressure on ecosystems resulting from freshwater withdrawal. Through reuse, wastewater is no longer considered a "pure waste" that potentially harms the environment, but rather an additional resource that can be harnessed to achieve water sustainability [12].

A water desalination technology for thermal power plants could be considered as a near-zero liquid discharge if the wastewater total dissolved solids (TDS) is not higher than TDS of raw water, and as a zero liquid discharge if no effluent is left over. A Zero liquid discharge facility is an industrial plant that eliminates liquid waste leaving the power plant, with the majority of water being recovered for reuse. This target could only be reached using integrated approach to solving the thermal power plant wide problem of wastewater formation, reclamation and reuse [13].

One of the possible ways of reducing the total amount of wastewater discharges is that at least $50 \%$ of makeup water treatment plant wastewaters (including all wastewaters from pretreatment, waste waters after ionite filters backwash and also water discharged when emptying clarification and ionite filters) have the same or even better salinity, hardness, alkalinity and other indicators than those of the pretreated water as well as of raw water. That is why such wastewaters could be used as a raw water for clarification filters or even for 
Sodium-cationite filters without additional chemicals added. To further minimize the amount of thermal power plant wastewaters the following measures must be taken [14]:

- water desalination using counter-current ion exchange technologies;

- thoroughfare regeneration of a weak and a strong resin filters connected in series (the regenerant pass first through the strong, then through the weak resin filter) (fig. 1);

- rinse recycling and reuse;

- partial water desalination using membrane technologies (reverse osmosis (RO), electrodialysis (EDI), electro deionization);

- application of thermal desalination technologies [15] (multi-stage flash distillation (fig. 2), multiple-effect distillation (fig. 3)) [14];

- implementation of electrodialysis to the recovery of acids and alkali from thermal power plants acidic and alkaline wastewaters correspondently;

- application of electrodeionization;

- application of electrocoagulation.
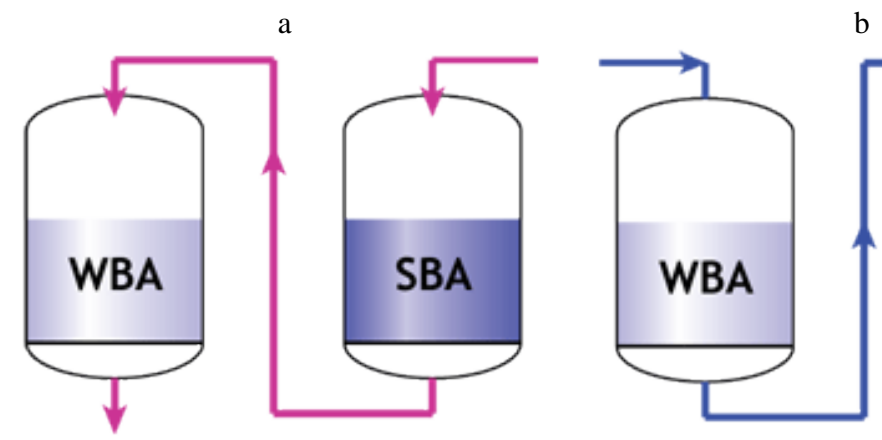

b

Fig. 1. Ion exchange process regeneration: $\mathrm{a}$ - separate columns in service; $\mathrm{b}$ - separate columns in regeneration

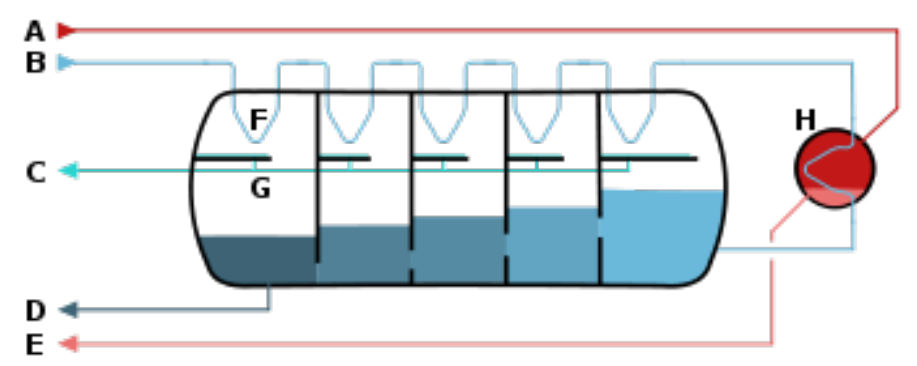

Fig. 2. The schematic of a 'once-through' multi-stage flash desalinator: A - steam in; $\mathrm{B}$ - seawater in; C - potable water out; D - waste out; E - steam out; F - heat exchange; $\mathrm{G}$ - condensation collection; $\mathrm{H}$ - brine heater

Theoretically, the most promising zero liquid discharge technology is thermal desalination, where the feed wastewater undergoes a pretreatment step that reduces scaling potential, and is then concentrated sequentially by two core elements a brine concentrator and a brine crystallizer (or an evaporation pond) [16]. 
The distillates generated by the brine concentrator and crystallizer units are reused as clean product water, whereas the solids produced are either stored (in evaporation ponds), further processed for landfill disposal, or reused as valuable byproducts. But taking into account high capital cost as well as intensive energy consumption required, this way of solving the thermal power plant wide problem of wastewater formation, reclamation and reuse is considered as not viable [17]. A water desalination technology could be considered as a viable one when the produced solids are recovered as valuable salt byproducts or when the amount of wastewater formation is at minimum possible level [18].

But while designing low-waste water treatment plants the following problems occur [19]:

- absence of serial equipment for production of solids (the absence of brine crystallizers for sedimentation of substances with low solubility; absence of reactors that allow to recover separate components from produced solids; absence of regulating and shut-

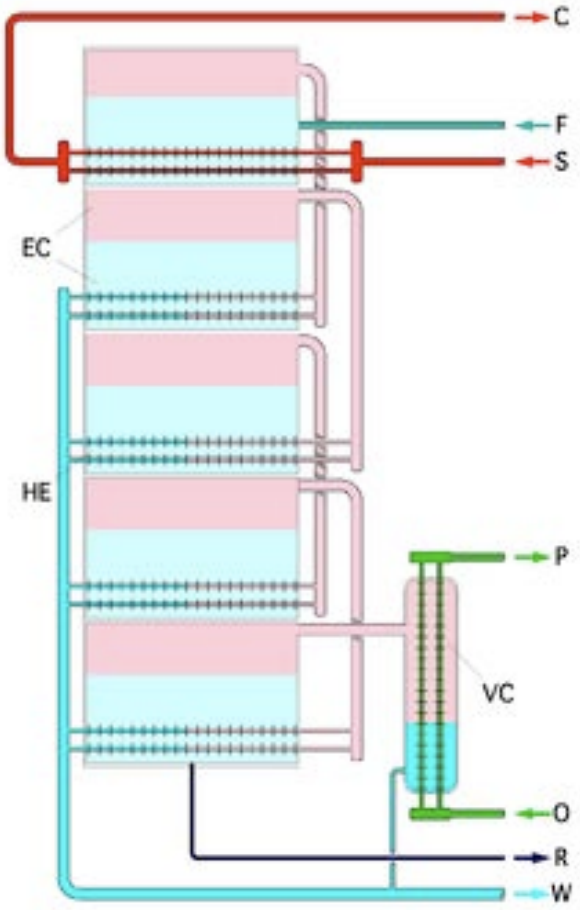

Fig. 3. Schematic of a multiple effect of the desalination plant (the first stage is at the top): the pink areas - vapor; the lighter blue areas - liquid feed water; dark turquoise - condensate;

$\mathrm{F}$ - feed water in; $\mathrm{S}$ - heating steam in;

$\mathrm{C}$ - heating steam out; $\mathrm{W}$ - fresh water (condensate) out; $\mathrm{R}$ - brine out; $\mathrm{O}$ - coolant in; P - coolant out; $\mathrm{VC}$ - the last-stage cooler off valves for corrosive-active agents);

- absence of serial equipment for deep concentrating of wastewaters;

- absence of technologies of recovering valuable salt byproducts from waste;

- absence of systems of automatic control and analysis of zero liquid discharge technologies.

In recent years membrane desalination technologies has emerged as the most viable solution to environmental impact reduction [20,21]. The possibility of dissolved solids and organic impurities removal with almost no chemicals added predetermines the current interest to the use of these technologies for water desalination on thermal and nuclear power plants in the Republic of Belarus [22].

Of the many available desalination technologies, two membrane processes reverse osmosis and electrodialysis - are most widely used in power engineering [23]. Such widespread use would not have been possible without the advances made in membrane technology over the last decades. Depending on the nature of driving forces applied, ion exchange membranes (cationite, anionite, bipolar) let through the water but retains the salt and other impurities or vice 
versa. In particular, by applying a pressure difference (reverse osmosis), the permeating component(s), in most applications nearly exclusively water, are forced through the semi-permeable membrane while all ions are rejected to the maximum extent [24]. However, when applying an electric potential as the driving force to remove dissolved ions, ion exchange membranes selectively permit the transport of counter ions but prevent the passage of co-ions.

The positive aspect of membrane technologies application is almost complete automation of the chemical water treatment system and 3-4 times reduction the costs of traditional chemicals use (acid, alkali, salt), qualitative change of waste water chemical composition [20, 25].

The experience of operation of reverse osmosis installations shows that the main factor that affects the satisfactory performance of the membrane is the observance of the norms of quality of raw water supplied to the installation [26]. The analysis manufacturers' requirements shows that there is virtually no restrictions to total dissolved solids in fresh water to be treated in reverse osmosis units. The units can operate in a wide range of $\mathrm{pH}$ too. Only the content of the substances that can cause poisoning or clogging of the membranes are limited [20]. However, RO, although much more energy efficient than thermal evaporation, can be applied only to feedwaters with a limited salinity range.

Electrodialysis (fig. 4) is another membrane-based process but it is worth applying only to feedwaters with a high salinity $(1.5-15.0 \mathrm{~g} / \mathrm{l})$. That is why electrodialysis is widely applied in sea water desalination and industrial wastewater management $[27,28]$.

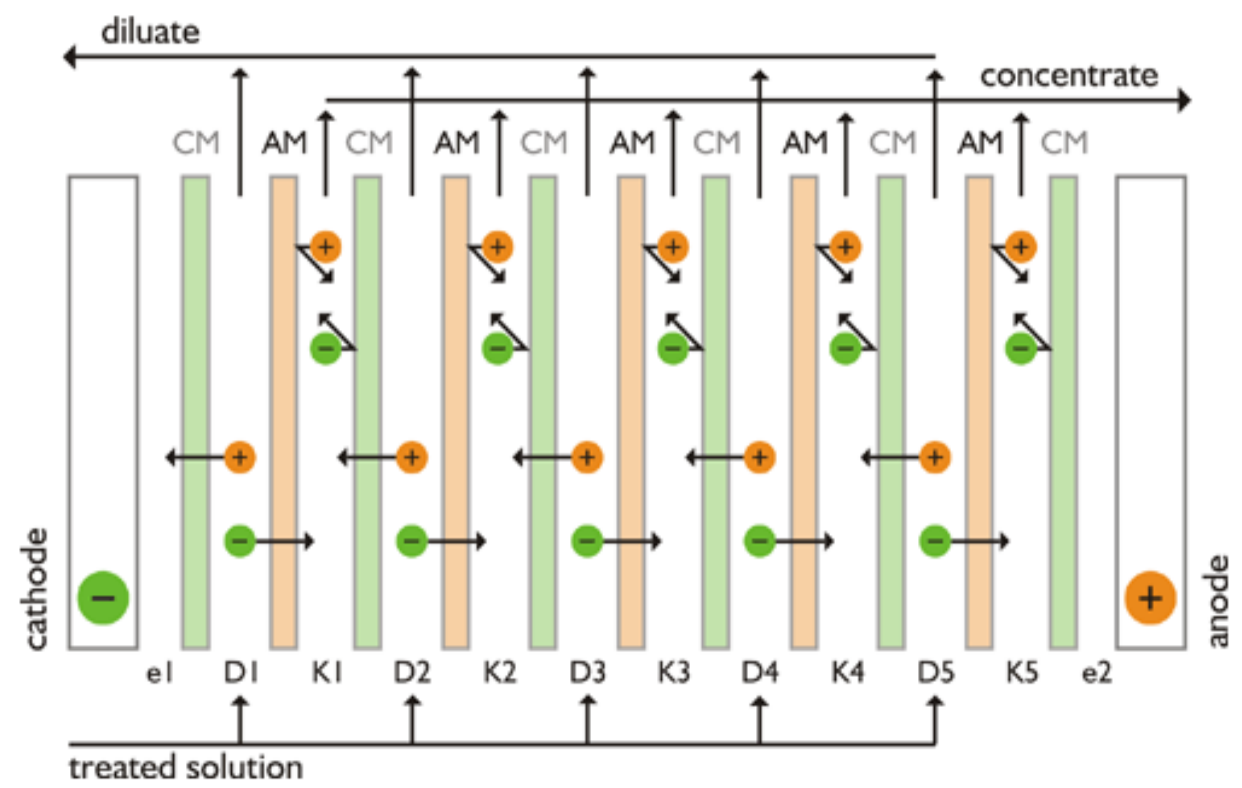

Fig. 4. The scheme of ion separation in membrane bundle: CM - cation exchange membrane; D - diluate chamber; e1, e2 - electrode chambers; AM - anion exchange membrane; $\mathrm{K}$ - concentrate chamber 
Electrodialysis applies an electric potential as the driving force to remove dissolved ions through ion exchange membranes. In contrast to RO membranes that reject all ions, ion exchange membranes selectively permit the transport of counter-ions but prevent the passage of co-ions [29].

The amount of energy consumption depends both on the feed water quality, which is mainly characterized by its total dissolved solids content (TDS value), and on the membrane quality. Electrodialysis membranes must meet the following requirements [30]:

- high selectivity;

- low permeability for water;

- conductivity;

- high chemical stability.

The development and practical application of technological schemes of the most dangerous for hydrosphere acidic and alkaline wastewaters treatment is the possible way of reducing the negative impact of thermal and nuclear power plants on the hydrosphere too [31, 32]. The most promising way of extracting acids and alkali from such wastewaters is the development and practical application of electrodialysis units.

Considering the bipolar membrane electrodialysis unit as a black box, it allows to produce an acid and a base from a neutral salt feed stream (fig. 4). Bipolar membrane electrodialysis can become interesting if either the acid or the base is the desired product [33].

Promising applications have been investigated in acid and base production, in the acidification of product streams, or for special separations, such as the separation of amino-acids on the basis of their isoelectric points [34]. The economically most interesting applications can reduce side products or achieve process schemes not possible before [35]. As an example, sodium lactate from a fermentation step can be converted into lactic acid by bipolar membrane electrodialysis [36]. The side product, sodium hydroxide, can be used to control the fermentation reaction. Designing bipolar membrane, electrodialysis provides increasing prospects for its economic feasibility, however, it also increases the complexity and challenges that have to be met.

However, there are some difficulties when using electrodialysis units for wastewater treatment. The reasons of these difficulties are [37]:

- high salinity of water to be treated that results in high current density; it can cause membranes burnout in case of irregular operation of membrane cells;

- high organic impurities and iron compounds content in waste water that can result in membrane poisoning;

- diffusion and electroosmotic processes when the salinity difference between concentrate chambers and dilute chambers is high;

- the possibility of insoluble compounds formation on membranes' surfaces.

Electrodeionization uses the water purification benefits of ion exchange resin while eliminating the disadvantages of chemical regeneration, which is done by combining ion exchange resin with electrodialysis. The elements required for the electrodialysis (EDI) process consist of ion selective cation and anion mem- 
branes, electrodes, concentrate chambers, dilute chambers and direct (DC) current. The result is electrodeionization, which is a continuous, chemical-free system which generates high resistivity water. However, some problems can occur inside the electrodeionization modules when operating requirements aren't met:

- irreversible scaling in the concentrate chamber when recovery rate and feed water quality isn't be controlled strictly (recovery rate is determined by the feed water total hardness);

- severe and irreversible module damage when feed water specifications isn't strictly adhered to;

- buildup when gases (hydrogen, oxygen, chlorine) from water electrolysis been produced at the electrodes and carried away in the electrode flush and concentrate stream aren't vented;

- poor EDI performance and/or irreversible scaling in the concentrating chambers due to polymerization of silica when influent silica levels are high.

Other desalination technologies are used less widely due to their rudimentary development and/or higher cost. However, there is no single desalination technology that is considered "best" for all uses. The selection of the most appropriate technology depends on the composition of the feed water (prior to desalination), the desired quality of the product water, and many other site-specific factors.

The proper choice of a desalination technology to be applied will depend on the feed water quality, which is mainly characterized by its total dissolved solids content (TDS value). The treated water quality requires so that the costs and environmental impact of the desalination technology applied must be minimized [36, 38, 39].

\section{CONCLUSIONS}

1. In the present work the main directions of water desalination technologies improving are analyzed. The comparative analysis of desalination technologies for the design of low-waste water treatment is carried out. The comparative evaluation of ecological efficiency of ion exchange and membrane desalination schemes of water desalination on thermal and nuclear power plants is obtained.

2. The results of research can be applied for the design of new and the modernization of existing water treatment plants of thermal power plants. It will allow to considerably reduce the use of natural water and the amount of chemicals added as well as the volume of wastewater and the concentration of dissolved solids in it. It will help to reduce the negative impact of thermal power plants on the hydrosphere.

\section{REFERENCES}

1. Rimashevskaya E. D. (2015) The State of the Technology of Preparation of Water of Working Medium at a Heat Power Plant of the Republic of Belarus. Aktualnye Problemy Energetiki: Materialy 71-i Nauch.-Tekhn. Konf. Studentov i Aspirantov [Topical Problems of Power Engineering: Proceedings of the $71^{\text {st }}$ Scientific-and-Technical Conference of Students]. Minsk, Belarusian National Technical University, 226-227 (in Russian).

2. Rimashevskaya E. D. (2015) Analysis of Technical Efficiency of the Use of the Promising Patterns of Ion Exchangers in Water Demineralization in Nuclear Power Plants. Energetika: 
Effektivnost, Nadezhnost, Bezopasnost: Materialy XXI Vseros. Nauch.-Tekhn. Konf. T. 1 [Energy: Efficiency, Reliability, Safety: Proceedings of the XXI ${ }^{\text {st }}$ All-Russian Scientific-andTechnical Conference. Vol. 1]. Tomsk, Tomsk Polytechnic University, 261-263 (in Russian).

3. Tong T., Elimelech M. (2016) The Global Rise of Zero Liquid Discharge for Wastewater Management: Drivers, Technologies and Future Directions. Environmental Science \& Technology, 50 (13), 6846-6855. DOI: 10.1021/acs.est.6b01000.

4. Rimashevskaya E. D. (2015) Improvement of Low-Waste Technologies of Chemical Water Purification. Aktualnye Problemy Energetiki: Materialy 71-i Nauch.-Tekhn. Konf. Studentov i Aspirantov [Topical Problems of Power Engineering: Proceedings of the $71^{\text {st }}$ Scientific-andTechnical Conference of Students]. Minsk, Belarusian National Technical University, 254-257 (in Russian).

5. Chizh V. A., Rimashevskaya E. D. (2014) Ways to Improve Pre-Treatment of Water at a Heat Power Plant. Energetika i Energosberezhenie: Teoriya i Praktika: Materialy I Vseros. Nauch.Prakt. Konf. [Energy and Energy Efficiency: Theory and Practice. Proceedings of the It AllRussian Scientific-and-Practical Conference]. Kemerovo, Kuzbas State Technical University named after T. F. Gorbachev. Available at: http://science.kuzstu.ru/wp-content/Events/Confe rence/Other/2014/oldenerg1/energ1/pages/Articles/1/Chizh.pdf. (Accessed: 1 August 2016) (in Russian).

6. Kosandrovich E. G., Soldatov V. S. (2012) Fibrous Ion Exchangers. Inamuddin Dr. Mohammad Luqman (eds.). Ion Exchange Technology: Theory and Materials. Springer, 299-371. DOI: 10.1007/978-94-007-1700-8_9.

7. Rimashevskaya E. D., Chizh V. A. (2016) The Use of Modern Environmental and ResourceSaving Technologies of Desalination of Water when Designing the Water Treatment Installations of Heat and Nuclear Power Plants. Sbornik Nauchnykh Rabot Studentov Respubliki Belarus "NIRS 2015" [Collection of Scientific Works of Students of the Republic of Belarus "NIRS 2015”]. Minsk, Publishing Center of the Belarusian State University, 124 (in Russian).

8. Tchobanoglous G., Leverenz H. (2009) Impacts of New Concepts and Technology on the Energy Sustainability of Wastewater Management. Conference on Climate Change, Sustainable Development and Renewable Resources in Greece, Oct. 17, 2009.

9. Larin B. M., Korotkov A. N., Oparin M. Yu., Larin A. B. (2010) Experience Gained from Putting New Technologies of Water Treatmentin Use at Thermal Power Stations. Teploenergetika [Thermal Engineering], 57 (8), 646-652. DOI: 10.1134/S0040601510080033.

10. Odoevtseva M. V., Chekunov S. S., Gromova I. V. (2015) Assessment of Efficiency of Application of the Combined Scheme of Treatment of Salted Drains. Alternative Energy and Ecology (ISJAEE), (17-18), 158-161 (in Russian). DOI:10.15518/isjaee.2015.17-18.025.

11. Grant S. B., Saphores J.-D., Feldman D. L., Hamilton A. J., Fletcher T. D., Cook P. L. M., Stewardson M., Sanders B. F., Levin L. A., Ambrose R. F., Deletic A., Brown R., Jiang S. C., Rosso D., Cooper W. J., Marusic I. (2012) Taking the "Waste" out of "Wastewater" for Human Water Security and Ecosystem Sustainability. Science, 2012, 337 (6095), 681-686. DOI: $10.1126 /$ science.1216852.

12. Chizh V. A., Rimashevskaya E. D. (2015) Improvement of Technologies for Purification and Neutralization of Waste Waters of Heat Power Plants Based on Membrane Methods. Energetika i Energosberezhenie: Teoriya i Praktika: Materialy II Vseros. Nauch.-Prakt. Konf. [Energy and Energy Efficiency: Theory and Practice. Proceedings of the Second All-Russian Scientific-and-Practical Conference]. Kemerovo, Kuzbas State Technical University named after T. F. Gorbachev. Available at: http://science.kuzstu.ru/wp-content/Events/Conference/ energ/2015/energ/pages/Articles/1/Chizh_Rimashevskaja.pdf. (Accessed: 1 August 2016) (in Russian).

13. Zhadan A. V. (2013) Improving the Technology of Water Treatment at Heat Power Plants on the Basis of Ion Exchange and Membrane Methods. Ivanovo, Ivanovo State Power University. 20 (in Russian).

14. Rodiana E. V., Rimashevskaya E. D. (2015) The Study of Computer Software Design of Remote Control Panels of Thermal and Nuclear Power Plants. Vestnik Rossiiskogo Natsionalnogo Komiteta CIGRE. Vyp. 7: Materialy Molodezhnoi Sektsii RNK SIGRE [Herald of the Russian National Committee of CIGRE. Issue 7: Materials of the Youth Section of CIGRE RNC: Collected Works Towards the Competition Presentations "Power-2015" in Electric Power and Electric Engineering Directions of CIGRE Research, Ivanovo, 21-23 April 2015]. Ivanovo, Ivanovo State Power University, 76-80 (in Russian). 
15. Bruinsma D., Spoelstra S. (2010) Heat Pumps in Distillation. Distillation \& Absorption Conference 12-15 September 2010, Eindhoven, Netherlands, 21-28.

16. Fardiev I. Sh., Zakirov I. A., Silov I. Yu., Galiev I. I., Korolev A. G., Shishchenko V. V., Sedlov A. S., Ilina I. P., Sidorova S. V., Khaziakhmetova F. R. (2009) Experience of Creating Complex Low-Waste System of Water Use at the Kazan CHP-3. Novoe v Rossiiskoi Elektroenergetike [New in Russian Power Industry], (3), 30-37 (in Russian).

17. Oren Y., Korngold E., Daltrophe N., Messalem R., Volkman Y., Aronov L., Weismann M., Bouriakov N., Glueckstern P., Gilron J. (2010) Pilot Studies on High Recovery BWRO-EDR for Near Zero Liquid Discharge Approach. Desalination, 261 (3), 321-330. DOI:10.1016/j. desal.2010.06.010.

18. Rimashevskaya E. D. (2016) Improving the Design of Water Treatment Facilities of Thermal and Nuclear Power Plants with the Use of Computer Technologies. Informatizatsiya Inzhenernogo Obrazovaniya - INFORINO-2016: tr. Mezhdunar. Nauch.-Metod. Konf. [Informatization of Engineering Education - INFORENE-2016 : Proceedings of the International Scientific-and-Methodic Conference, Moscow, 12-13 April 2016]. Moscow, Moscow Energy Institute, 415-419 (in Russian).

19. Rimashevskaya E. D. (2015) Development of a Small Drain Remote Control Panel of a CHP. Elektroenergetika Glazami Molodezhi: tr. VI Mezhdunar. Nauch.-Tekhnich. Konf. T. 1 [The Electric Power Industry Through the Eyes of Youth: Proceedings of the VI ${ }^{\text {th }}$ International Scientific-and-Technical Conference, Ivanovo, 9-13 November 2015. Vol. 1]. Ivanovo, Ivanovo Power Engineering Institute named after V. I. Lenin, 358-363 (in Russian).

20. Panteleev A. A., Ryabchikov B. E., Khoruzhii O. V., Gromov S. L., Sidorov A. R. (2012) Membrane Technologies in the Industrial Water Treatmen. Moscow, DeLi plus Publ. 429 (in Russian).

21. Panteleev A. A., Ryabchikov B. E., Zhadan A. V., Khoruzhii O. V. (2012) Design Solutions for Water Treatment Plants Constructed on the Basis of Membrane Technologies. Teploenergetika [Thermal Engineering], 59 (7), 517-523. DOI: 10.1134/S0040601512070142.

22. Rimashevskaya E. D. (2016) A Study of Environmental Efficiency of Baromembrane Schemes of Water Desalination at TPP. Energiya-2016: Odinnadtsataya Mezhdunar. Nauch.-Tekhn. Konf. Studentov, Aspir. i Molodykh Uchenykh: Materialy Konf. T. 1 [Energy-2016: the Eleventh International Scientific-and-Technical Conference of Students and Young Researchers. Vol. 1]. Ivanovo, Ivanovo Power Engineering Institute named after V. I. Lenin, 99-101 (in Russian).

23. Elimelech M., Phillip W. A. (2011) The Future of Seawater Desalination: Energy, Technology and the Environment. Science, 333 (6043), 712-717. DOI: 10.1126/science.1200488.

24. Gerard R., Laflamme R. (2008) Technology Selection Tools for Boiler Feedwater Application. Paper Presented at Abu Qir WTT Conference. Tech Paper GE 1160EN.

25. Vladana N. R., Dragana Z. Z., Branimir N. G. (2011) Improvement of Chemical Control in the Watersteam Cycle of Thermal Power Plants. Applied Thermal Engineering, 31 (1), 119-128. DOI: 10.1016/j.applthermaleng.2010.08.028.

26. Kucera J. (2015) Reverse Osmosis Industrial Processes and Application. $2^{\text {-nd }}$ ed. Canada, Scrivener Publ. 472. DOI: 10.1002/9781119145776.

27. Gruzdyev E., Starikov E. (2009) Water Treatment Plant with Use of Reverse Osmosis and Electrical Deionization Processes. Bulgarian Nuclear Energy - National, Regional and World Energy Safety: Materials of Belene NPP II International Nuclear Conference, 27-29 May 2009.

28. Kagramanov G. G., Farnosova E. N., Kandelaki G. L. (2010) Heavy Metal Cationic Wastewater Treatment with Membrane Methods. Václavíková M., Vitale K., Gallios G. P., Ivaničová L. (eds.) Water Treatment Technologies for the Removal of High-Toxicity Pollutants. NATO Science for Peace and Security Series C: Environmental Security. Springer, Dordrecht, 177-182. DOI: 10.1007/978-90-481-3497-7_15.

29. Xu T. W., Huang C. H. (2008) Electrodialysis-Based Separation Technologies: a Critical Review. AIChE Journal, 54 (12), 3147-3159. DOI: 10.1002/aic.11643.

30. Bildyukevich A., Branitsky G., Plisko T. (2010) Morphological Structure and Transport Properties of Polymer-Inorganic Membranes. V International Conference on Chemistry and Chemical Education "Sviridov Readings 2010”: Book of Abstracts. Minsk, Belarussian State University, 40. 
31. Fu Fenglian, Qi Wang (2011) Removal of Heavy Metal Ions from Wastewaters: a Review. Journal of Environmental Management, 92 (3), 407-418. DOI: 10.1016/j.jenvman. 2010.11.011.

32. Oller I., Malato S., Sánchez-Pérez J. A. (2011) Combination of Advanced Oxidation Processes and Biological, Treatments for Wastewater Decontamination - a Review. Science of the Total Environment, 409 (20), 4141-4166. DOI: 10.1016/j.scitotenv.2010.08.061.

33. Heidrich E. S., Curtis T. P., Dolfing J. (2011) Determination of the Internal Chemical Energy of Wastewater. Environmental Science and Technology, 45 (2), 827-832. DOI: 10.1021/es 103058w.

34. Rana D., Matsuura T., Kassim M. A., Ismail A. F. (2013) Radioactive Decontamination of Water by Membrane Processes - a Review. Desalination, 321, 77-92. DOI: 10.1016/j.desal. 2012.11.007.

35. Ojovan M. I., Lee W. E. (2011) Treatment of Radioactive Wastes. An Introduction to Nuclear Waste Immobilisation. Elsevier Ltd., 171-203.

36. Ghaffour N., Missimer T. M., Amy G. L. (2013) Technical Review and Evaluation of the Economics of Water Desalination: Current and Future Challenges for Better Water Supply Sustainability. Desalination, 309, 197-207. DOI: 10.1016/j.desal.2012.10.015.

37. DOWTM EDI-310 Module. Product Manual. Version 1. Form No 795-00051-1110. USA. 2010.

38. Rimashevskaya E. D., Chizh V. A. (2016) Experience of the Use of Computer Design Technologies of Water-Treatment Installations of Thermal and Nuclear Power Plants in the Educational Process at the Belarusian National Technical University. Materialy IX Mezhdunar. Vodno-Himicheskogo Foruma, g. Minsk, 17-19 Maja 2016 g. [Materials of the IX $^{\text {th }}$ International Water-Chemical Forum, Minsk, 17-19 May, 2016]. Minsk, Kovcheg Publ., 127-131 (in Russian).

39. Rimashevskaya E. D. (2016) The Development and Analysis of Technology of Recycling of Wastewater Sodium in the Preparation of Demineralized Water at a Heat Power Plant and Nuclear Power Plants in Accordance with the Baromembrane Methods. Energiya-2016: Odinnadtsataya Mezhdunar. Nauch.-Tekhn. Konf. Studentov, Asp. i Molodykh Uchenykh: Materialy Konf. T. 1 [Energy-2016: the Eleventh International Scientific-and-Technical Conference of Students and Young Researchers. Vol. 1]. Ivanovo, Ivanovo Power Engineering Institute named after V. I. Lenin, 101-102 (in Russian).

Received: 31 August $2016 \quad$ Accepted: 28 October $2016 \quad$ Published online: 28 July 2017

\section{ЛИТЕРАТУРА}

1. Римашевская, Е. Д. Состояние технологии подготовки водного рабочего тела на ТЭС Республики Беларусь / Е. Д. Римашевская // Актуальные проблемы энергетики: материалы 71-й науч.-техн. конф. студентов и аспирантов, Минск, 2015 г. / Белор. нац. техн. ун-т; редкол.: Т. Е. Жуковская. Минск, 2015. С. 226-227.

2. Римашевская, Е. Д. Анализ технологической эффективности использования перспективных ионитов в схемах обессоливания воды на атомных электростанциях / Е. Д. Римашевская // Энергетика: эффективность, надежность, безопасность: материалы XXI всеpoc. науч.-техн. конф.: в 2 т., Томск, 2-4 дек. 2015 г. / Томский политехн. ун-т; редкол.: В. В. Литвак [и др.]. Томск, 2015. Т. 1. С. 261-263.

3. Tong, T. The Global Rise of Zero Liquid Discharge for Wastewater Management: Drivers, Technologies and Future Directions / T. Tong, M. Elimelech // Environmental Science \& Technology. 2016. Vol. 50, No 13. P. 6846-6855.

4. Римашевская, Е. Д. Совершенствование малоотходных технологий ХВО / Е. Д. Римашевская // Актуальные проблемы энергетики: материалы 71-й науч.-техн. конф. студентов и аспирантов, Минск, 2015 г. / Белор. нац. техн. ун-т; редкол.: Т. Е. Жуковская. Минск, 2015. С. 254-257.

5. Чиж, В. А. Пути совершенствования предварительной обработки воды на ТЭС [Электронный ресурс] / В. А. Чиж, Е. Д. Римашевская // Энергетика и энергосбережение: теория и практика: материалы I всерос. науч.-практ. конф., Кемерово, 3-5 дек. 2014 г. / ФГБОУ ВПО Кузбас. гос. техн. ун-т имени Т. Ф. Горбачева; редкол.: В. П. Тациенко (отв. редак- 
тор) [и др.]. Кемерово, 2014. Режим доступа: http://science.kuzstu.ru/wp-content/Events/ Conference/Other/2014/oldenerg1/energ1/pages/Articles/1/Chizh.pdf. Дата доступа: 01.08.2016.

6. Kosandrovich, E. G. Fibrous Ion Exchangers / E. G. Kosandrovich, V. S. Soldatov // Ion Exchange Technology: Theory and Materials / Eds. Dr. Inamuddin, M. Luqman. New York: Springer, 2012. P. 299-371.

7. Римашевская, Е. Д. Применение современных экологических и ресурсосберегающих технологий обессоливания воды при проектировании водоподготовительных установок тепловых и атомных электрических станций / Е. Д. Римашевская, В. А. Чиж // Сборник научных работ студентов Республики Беларусь «НИРС 2015». Минск: Издательский центр БГУ, 2016. С. 124.

8. Tchobanoglous, G. Impacts of New Concepts and Technology on the Energy Sustainability of Wastewater Management / G. Tchobanoglous, H. Leverenz // Conference on Climate Change, Sustainable Development and Renewable Resources in Greece, Oct. 17, 2009. Greece, 2009.

9. Опыт освоения новых технологий обработки воды на ТЭС / Б. М. Ларин [и др.] // Теплоэнергетика. 2010. Т. 57, № 8. С. 8-13.

10. Одоевцева, М. В. Оценка эффективности применения комбинированной схемы переработки засоленных стоков / М. В. Одоевцева, С. С. Чекунов, И. В. Громова // Альтернативная энергетика и экология (ISJAEE). 2015. № 17-18. С. 158-161.

11. Taking the "Waste" out of "Wastewater" for Human Water Security and Ecosystem Sustainability / S. B. Grant [et al.] // Science. 2012. Vol. 337, No 6095. P. 681-686.

12. Чиж, В. А. Совершенствование технологий очистки и нейтрализации сточных вод ТЭС на базе мембранных методов [Электронный ресурс] / В. А. Чиж, Е. Д. Римашевская // Энергетика и энергосбережение: теория и практика: материалы II всерос. науч.-практ. конф., Кемерово, 2-4 дек. 2015 г. / ФГБОУ ВО Кузбас. гос. техн. ун-т имени Т. Ф. Горбачева; редкол.: О. В. Тайлаков (отв. ред.), И. А. Лобур (зам. отв. ред.) [и др.]. Кемерово, 2015. Режим доступа: http://science.kuzstu.ru/wp-content/Events/Conference/energ/2015/ energ/pages/Articles/1/Chizh_Rimashevskaja.pdf. Дата доступа: 01.08.2016.

13. Жадан, А. В. Совершенствование технологии обработки воды на ТЭС на базе ионного обмена и мембранных методов / А. В. Жадан. Иваново: ИГЭУ, 2013. 20 с.

14. Родина, Е. В. Исследование компьютерных программ проектирования ВПУ ТЭС и АЭС / Е. В. Родина, Е. Д. Римашевская // Вестник Российского национального комитета СИГРЭ. Иваново: ИГЭУ, 2015. Вып. 7: Материалы молодежной секции РНК СИГРЭ: сб. конкурс. докл. «Энергия-2015» по электроэнергетической и электротехнической тематикам по направлениям исследований СИГРЭ по итогам Конкурса докладов в рамках $\mathrm{X}$ Междунар. науч.-техн. конф. студентов, аспирантов и молодых ученых «Энергия-2015», 21-23 апр. 2015 г. С. 76-80.

15. Bruinsma, D. Heat Pumps in Distillation / D. Bruinsma, S. Spoelstra // Distillation \& Absorption Conference, 12-15 Sept. 2010, Eindhoven, Netherlands. Netherlands, 2010. P. 21-28.

16. Опыт создания комплексной малоотходной системы водопользования на Казанской ТЭЦ-3 / И. Ш. Фардиев [и др.] // Новое в российской электроэнергетике. 2009. № 3. C. $30-37$.

17. Pilot Studies on High Recovery BWRO-EDR for Near Zero Liquid Discharge Approach / Y. Oren [et al.] // Desalination. 2010. No 261 (3). P. 321-330.

18. Римашевская, Е. Д. Совершенствование проектирования водоподготовительных установок тепловых и атомных электрических станций с использованием компьютерных технологий / Е. Д. Римашевская // Информатизация инженерного образования ИНФОРИНО-2016: тр. Междунар. науч.-метод. конф. Москва, 12-13 апр. 2016 г. / МЭИ; редкол.: С. А. Позднеев (рецензент) [и др.]. М., 2016. С. 415-419.

19. Римашевская, Е. Д. Разработка малосточной ВПУ ТЭЦ / Е. Д. Римашевская // Электроэнергетика глазами молодежи: тр. VI междунар. науч.-технич. конф., Иваново, 9-13 нояб. 2015 г.: в 2 т / ФГБОУВПО Ивановский госуд. энергет. ун-т имени В. И. Ленина; редкол.: В. В. Тютиков (отв. ред.) [и др.]. Иваново, 2015. Т. 1. С. 358-363.

20. Технологии мембранного разделения в промышленной водоподготовке / А. А. Пантелеев [и др.]. Москва: ДеЛи плюс, 2012. 429 с.

21. Проектные решения водоподготовительных установок на основе мембранных технологий / А. А. Пантелеев [и др.] // Теплоэнергетика. 2012. Т. 59, № 7. С. 30-36. 
22. Римашевская, Е. Д. Исследование экологической эффективности баромембранных схем обессоливания воды на ТЭС и АЭС / Е. Д. Римашевская // Энергия-2016: Одиннадцатая междунар. науч.-техн. конф. студентов, асп. и молодых ученых: материалы конф.: в 7 т. $/$ ИГЭУ; оргкомитет: В. В. Тютиков (пред. оргком.) [и др.]. Иваново, 2016. Т. 1. С. 99-101.

23. Elimelech, M. The Future of Seawater Desalination: Energy, Technology and the Environment / M. Elimelech, W. A. Phillip // Science. 2011. No 333 (6043). P. 712-717.

24. Gerard, R. Technology Selection Tools for Boiler Feedwater Application / R. Gerard, R. Laflamme // Paper Presented at Abu Qir WTT Conference. 2008. Tech Paper GE 1160EN.

25. Vladana, N. R. Improvement of Chemical Control in the Watersteam Cycle of Thermal Power Plants / N. R. Vladana, Z. Z. Dragana, N. G. Branimir // Applied Thermal Engineering. 2011. No 31 (1). P. 119-128.

26. Kucera, J. Reverse Osmosis Industrial Processes and Application / J. Kucera. $2^{\text {nd }}$ edition. Canada: Scrivener Publ., 2015. 472 p.

27. Gruzdyev, E. Water Treatment Plant with Use of Reverse Osmosis and Electrical Deionization Processes / E. Gruzdyev, E. Starikov // Bulgarian Nuclear Energy - National, Regional and World Energy Safety: Materials of Belene NPP II International Nuclear Conference, 27-29 May 2009. Belene, 2009.

28. Kagramanov, G. G. Heavy Metal Cationic Treatment with Membrane Methods / G. G. Kagramanov, E. N. Farnosova, G. L. Kandelaki // Water Treatment Technologies for the Removal of High-Toxicity Pollutants / eds. M. Václavíková, K. Vitale, G. P. Gallios, L. Ivaničová. Dordrecht: Springer, 2010. P. 177-182. (NATO Science for Peace and Security Series C: Environmental Security).

29. Xu, T. W. Electrodialysis-Based Separation Technologies: a Critical Review / T. W. Xu, C. H. Huang // AIChE Journal. 2008. Vol. 54, No 12. P. 3147-3159.

30. Bildyukevich, A. Morphological Structure and Transport Properties of Polymer-Inorganic Membranes / A. Bildyukevich, G. Branitsky, T. Plisko // V International Conference on Chemistry and Chemical Education "Sviridov Readings 2010": Book of Abstracts, Minsk, Belarus, 6-9 April, 2010 / Belarussian State University; edit.: E. I. Vasilevskaya [et al.]. Minsk, 2010. P. 40.

31. Fu, Fenglian. Removal of Heavy Metal Ions from Wastewaters: a Review / Fenglian Fu, Qi Wang // Journal of Environmental Management. 2011. Vol. 92, No 3. P. 407-418.

32. Oller, I. Combination of Advanced Oxidation Processes and Biological, Treatments for Wastewater Decontamination - a Review / I. Oller, S. Malato, J. A. Sánchez-Pérez // Science of the Total Environment. 2011. Vol. 409, No 20. P. 4141-4166

33. Heidrich, E. S. Determination of the Internal Chemical Energy of Wastewater / E. S. Heidrich, T. P. Curtis, J. Dolfing // Environmental Science and Technology. 2011. Vol. 45, No 2. P. 827-832.

34. Radioactive Decontamination of Water by Membrane Processes - a Review / D. Rana [et al.] // Desalination. 2013. Vol. 321. P. 77-92.

35. Ojovan, M. I. Treatment of Radioactive Wastes / M. I. Ojovan, W. E. Lee // An Introduction to Nuclear Waste Immobilisation. Elsevier Ltd., 2011. P. 171-203.

36. Ghaffour, N. Technical Review and Evaluation of the Economics of Water Desalination: Current and Future Challenges for Better Water Supply Sustainability / N. Ghaffour, T. M. Missimer, G. L. Amy // Desalination. 2013. No 309. P. 197-207.

37. DOWTM EDI-310 Module. Product Manual. Version 1. Form No 795-00051-1110. USA. 2010.

38. Римашевская, Е. Д. Опыт использования компьютерных технологий проектирования водоподготовительных установок тепловых и атомных электрических станций в учебном процессе Белорусского национального технического университета / Е. Д. Римашевская, В. А. Чиж // Материалы IX междунар. водно-хим. форума, г. Минск, 17-19 мая 2016 г. / Инс-т физ.-орган. химии НАН Беларуси. Минск: Ковчег, 2016. С. 127-131.

39. Римашевская, Е. Д. Разработка и анализ технологий утилизации натрийсодержащих стоков при подготовке обессоленной воды на ТЭС и АЭС по баромембранным методам / Е. Д. Римашевская // «Энергия-2016»: Одиннадцатая междун. науч.-техн. конф. студентов, асп. и молодых ученых: материалы конф.: в 7 т. / ИГЭУ; оргкомитет: В. В. Тютиков (пред. оргком.) [и др.]. Иваново, 2016. Т. 1. С. 101-102.

Поступила 31.08.2016 Подписана в печать 28.10.2016 Опубликована онлайн 28.07.2017 